\title{
First report of Neoscytalidium novaehollandiae associated with stem canker and branch dieback of almond trees
}

\author{
E. Ören ${ }^{1} \cdot$ G. Koca ${ }^{1} \cdot$ R. Gencer ${ }^{2} \cdot$ H. Bayraktar ${ }^{3}$
}

Received: 30 January 2020 / Accepted: 24 March 2020 / Published online: 10 April 2020

(C) Australasian Plant Pathology Society Inc. 2020

\begin{abstract}
In 2019, a new disease of stem canker with branches dieback was observed in several commercial orchards in Diyarbakır province, Turkey. The pathogen was identified as Neoscytalidium novaehollandiae based on morphological characteristics and phylogenetic analysis of both internal transcribed spacer and transcription elongation factor 1- $\alpha$ regions. Koch's postulates were confirmed by successful reisolation of $N$. novaehollandiae only from plants inoculated with the pathogen. This is thought to be the first report of $N$. novaehollandiae causing stem canker of almond trees.
\end{abstract}

Keywords Almond Neoscytalidium novaehollandiae stem canker

Almond (Prunus dulcis) is considered an economically important fruit crop worldwide. Turkey is the world's fifth largest almond producer with a production of 90.000 tons and a cultivated area of 34.050 ha (Faostat 2019). Almond orchards have continuously increased especially in the South East Anatolia region of Turkey. Trunk and canker diseases are a potential threats to almond production in Turkey. Some Botryosphaeriaceous fungi (Neofusicoccum parvum and Diplodia sp.) have been reported to cause wood canker and dieback symptoms on almond trees (Kayım et al. 2015).

In the summer of 2019, during a survey of diseased almond trees in commercial orchards in the localities Sur, Çermik, and Eğil of Diyarbakır province, symptoms of trunk diseases were observed, including yellowing and defoliation of leaves, stem canker, branch dieback, gummosis, vascular discoloration, and tree death (Fig. 1). To identify the causal agents, small pieces of necrotic tissues were collected from stem and branches of seven trees, surface disinfected with $2 \% \mathrm{NaOCl}$ for $2 \mathrm{~min}$, rinsed with sterile distilled water and plated onto potato dextrose agar (PDA) amended with $0.5 \mathrm{~g} \mathrm{~L}^{-1}$ streptomycin sulfate. Plates were maintained at $25^{\circ} \mathrm{C}$ in dark and growing colonies were examined for

H. Bayraktar

bayrakta@agri.ankara.edu.tr

1 Diyarbakır Plant Protection Research Institute, 21110 Diyarbakır, Turkey

2 Bornova Plant Protection Research Institute, 35040 Izmir, Turkey

3 Faculty of Agriculture, Plant Protection Department, Ankara University, 06110 Ankara, Turkey cultural and morphological characteristics. All affected tissues consistently developed colonies with a white mycelium, becoming dark gray to black within a week. A total of 11 isolates were identified as Neoscytalidium-like based on morphological characteristics. Conidia were dark brown, thick-walled, cylindrical to oblong, 0 to 1 septate, 6.0 to $7.5 \times 3.5$ to $4.4 \mu \mathrm{m}(n=30)$, formed both singly and in disarticulating arthric chains from the aerial mycelium. Pycnidia observed on pine needles in the culture were stromatic, semi-immersed, and black. Conidia were ellipsoidal to oval, apices rounded, initially hyaline, becoming sepia $0-1$-septate or 2 -septate, $11.3 \times 4.5 \mu \mathrm{m}$. The morphological characteristics of the isolates coincided with those of Neoscytalidium novaehollandiae (Phillips et al. 2013). Also, the identification of the causal fungi was confirmed by DNA sequencing analysis.

Genomic DNA of the representative $N$. novaehollandiae isolate An-2 was isolated using Qiagen plant tissue DNA extraction kit according to the manufacturer's instructions (Oiagen, USA). The internal transcribed spacer (ITS) nrDNA and translation elongation factor $1-\alpha(E F 1-\alpha)$ gene regions were amplified using the primers ITS1/4 (White et al. 1990), and EF1- 728F/986R (Carbone and Kohn 1999). The amplified DNA products were sequenced in both directions using PCR primers (Macrogen, Inc., Seoul, Korea). The sequences were edited by Lasergene software package (DNASTAR, Madison, WI, USA) and compared with the sequences previously deposited in GenBank. NCBI-BLASTn analysis of the resultant sequences showed a high identify (EF1- $\alpha, 99.3$; ITS, 100\%) with reference sequence of N. novaehollandiae WAC 12691 (EF1- $\alpha$, EF585574; ITS, NR111260). Also, the sequences were aligned by the 
Fig. 1 Disease symptoms caused by Neoscytalidium

novaehollandiae associated with stem canker and branch dieback on almond tree. (a) branch dieback symptoms on almond tree, (b) vascular discoloration of the wood tissue (c) necrotic lesion on almond stem inoculated with the pathogen (a)

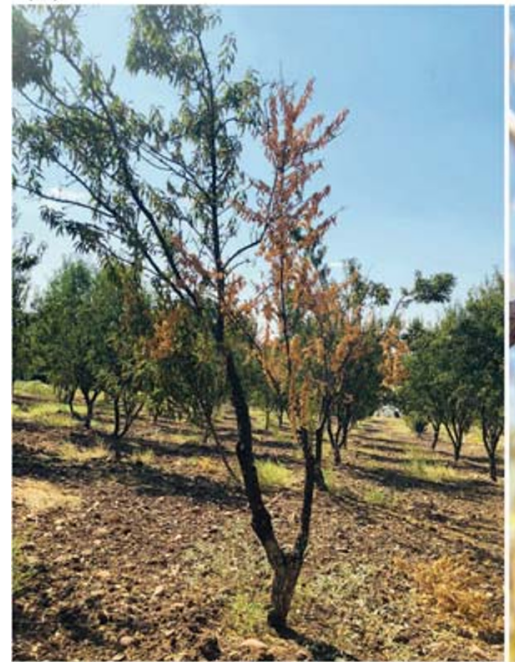

(b)

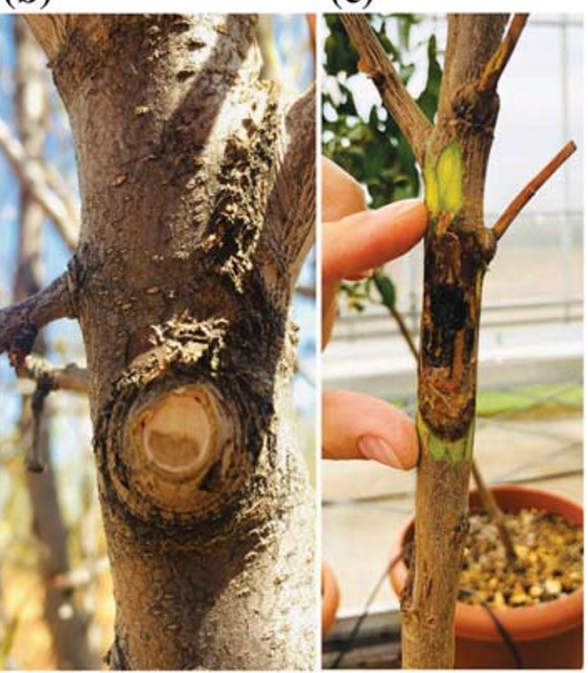

MEGA 7.0 software package and used to construct a phylogenetic tree with Neighbor-joining method based on 1000 bootstrap replicates. A sequence of Botryosphaeria dothidea was selected as an outgroup (Fig. 2). The pathogen obtained from almond trees was closely related to $N$. novaehollandiae isolates from different hosts. The sequences obtained were deposited in the GenBank database with accession numbers (ITS: MN982949, EF1- $\alpha$ : MN990035). The isolate An-2 was deposited in Erciyes University Culture Collection (EUCC WDCM1202) with the accession number EUCC-2920 M.
Fig. 2 Phylogenetic tree obtained by the neighbour-joining method from the partial sequences of nrDNA ITS and EF1- $\alpha$ gene regions of Neoscytalidium spp. isolates. Botryosphaeria dothidea is included as outgroup. Bootstrap values are shown as percentages of 1000 replicates

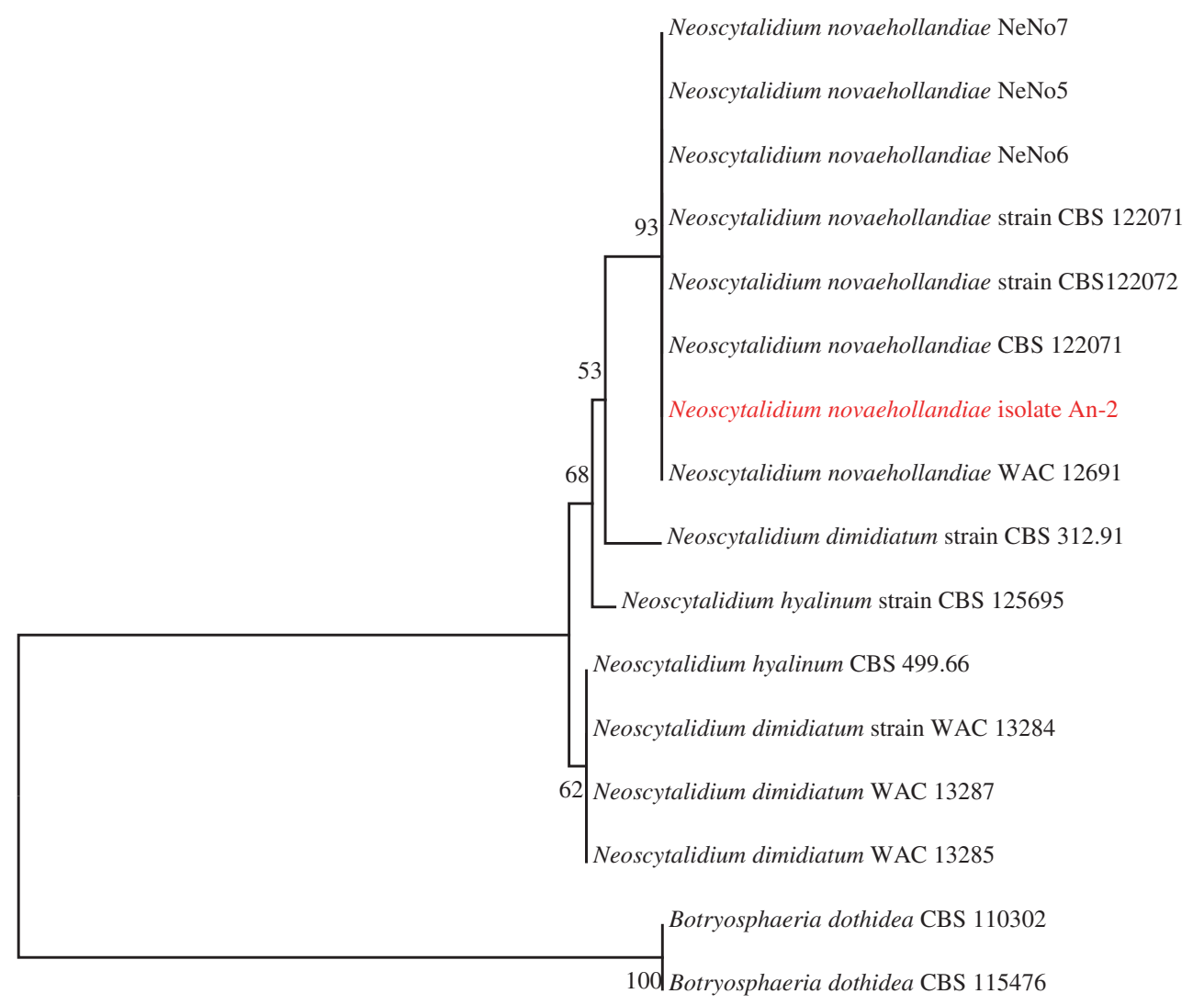

$\longmapsto .0100$ 
Pathogenicity tests were carried out on five 2-year-old almond trees cv. Ferragnes with the isolate An-2. The outer bark at the inoculation site was surface sterilized with $70 \%$ ethanol and a 5mm diameter wound was created in the stem with a cork borer up to bark depth. A 5-mm-diameter disc from a 10-day-old culture on PDA was then placed on each wound and immediately covered with Parafilm. Sterile PDA plugs were deposited on the wounds of control plants. Inoculated plants were maintained in a greenhouse with a temperature range of $25 \pm 2{ }^{\circ} \mathrm{C}$. After 1month, all inoculated plants showed necrotic lesions with a mean length of $3.3 \mathrm{~cm}$. No symptoms were observed in the control plants. The pathogen was reisolated from lesions of inoculated stems, thus fullling Koch's postulates.

Neoscytalidium spp. described by Crous et al. (2006) was an important pathogen group associated with dieback and cankers of woody plants worldwide. Neoscytalidium novaehollandiae has been reported from different hosts such as Mangifera indica, Adansonia gibbosa, Acacia synchronica, Crotalaria medicaginea, and Grevillia agrifolia (Pavlic et al. 2008; Ray et al. 2010). The pathogen has been recently observed to cause wood canker of grapevine in Turkey (Akgül et al. 2019). However, to our knowledge, this is the first report of $N$. novaehollandiae associated with stem canker and branch dieback of almond trees.

\section{References}

Akgül DS, Savaş NG, Özarslandan M (2019) First report of wood canker caused by Lasiodiplodia exigua and Neoscytalidium novaehollandiae on grapevine in Turkey. Plant Dis 103(5):1036. https://doi.org/10.1094/PDIS-11-18-1938-PDN

Carbone I, Kohn LM (1999) A method for designing primer sets for speciation studies in filamentous ascomycetes. Mycologia 91:553556. https://doi.org/10.2307/3761358

Crous PW, Slippers B, Wingfield MJ, Rheeder J, Marasas WF, Philips AJ, Alves A, Burgess T, Barber P, Groenewald JZ (2006) Phylogenetic lineages in the Botryosphaeriaceae. Stud Mycol 1(55):235-253. https://doi.org/10.3114/sim.55.1.235

Faostat (2019) Food and agriculture organization of the United Nations. Statistical database. www.fao.org/faostat/en/\#data/QC. Accessed 17 November 2019

Kayım M, Endes A, Eskalen A (2015) First report of Neofusicoccum parvum and Diplodia sp. associated with wood canker and dieback on almond in Turkey. XVIII. International plant protection congress (IPPC), Berlin, Germany p.798

Pavlic D, Wingfield MJ, Barber P, Slippers B, Hardy GE, Burgess TI (2008) Seven new species of the Botryosphaeriaceae from baobab and other native trees in Western Australia. Mycologia 100(6):851866. https://doi.org/10.3852/08-020

Phillips AJ, Alves A, Abdollahzadeh J, Slippers B, Wingfield MJ, Groenewald JZ, Crous PW (2013) The Botryosphaeriaceae: genera and species known from culture. Stud Mycol 76:51-167. https://doi. org/10.3114/sim0021

Ray JD, Burgess T, Lanoiselet VM (2010) First record of Neoscytalidium dimidiatum and N. novaehollandiae on Mangifera indica and N. dimidiatum on Ficus carica in Australia. Aust Plant Dis Notes 5:48-50. https://doi.org/10.1071/DN10018

White TJ, Bruns T, Lee S, Taylor J (1990) Amplification and direct sequencing of fungal ribosomal RNA genes for phylogenetics. In: Innis MA, Gelfand DH, Sninsky JJ, White TJ (eds) PCR protocols, a guide to methods and applications. Academic Press, San Diego, pp 315-322 